\section{A Northern Pecan Pollen Source Delays Germination of Nuts from a Southern Pecan Cultivar}

\author{
Shyi-kuan Ou${ }^{1}$ and J. Benton Storey ${ }^{2}$ \\ Department of Horticultural Science, Texas Agricultural Experiment Station, \\ Texas A\&M University, College Station, TX 77843
}

Tommy E. Thompson ${ }^{3}$

U.S. Department of Agriculture, Agricultural Research Service, Pecan Genetics and Breeding Station, Route 2, Box 133, Somerville, TX 77879

Additional index words. Carya illinoinensis, viviparity, xenia, preharvest germination

\begin{abstract}
Preharvest germination (viviparity) can be a problem with nuts of pecan [Carya illinoinensis (Wangenh.) K. Koch]. Two southern-adapted cultivars ('Cherokee' and 'Wichita') and one northern-adapted cultivar ('Johnson') were paternal parents in controlled crosses with the maternal parent 'Wichita'. 'Wichita' $x$ 'Johnson' seed took much longer to germinate than seed from either the 'Wichita' $x$ 'Cherokee' cross or the 'Wichita' self, therefore indicating that pollen source may influence germination characteristics.
\end{abstract}

Preharvest germination (i.e., viviparity) is a serious problem for many pecan cultivars growing in the southwestern United States and northern Mexico (Brison, 1974; Zertuche, 1986). Viviparity usually destroys nut quality and renders nuts unmarketable. The degree of viviparity varies as a result of crop load (Finch and Van Horn, 1936; Stein, 1985; Zertuche, 1986), irrigation (L.W. Shreve, personal communication), tree crowding, or soil depth(G.R. McEachern, personal communication), and length of growing season (Finch, 1933). He reported that the longer the nuts remained on the tree, the greater the proportion of nuts germinating before harvest. Pollen source has been observed to influence fruit characteristics in relation to time of maturity (Swingle, 1928); shape (Uppal and Mukherjee, 1969); size (Iyer and Randhawa, 1965; Nixon, 1928, 1935; Uppal and Murkherjee, 1969); number of seeds per fruit (Iyer and Randhawa, 1965); germination (Avramov and Telenkovic, 1961); quality, color, time of fruit ripening (Nixon,

Received for publication 10 June 1994. Accepted for publication 15 June 1994. Part of a dissertation submitted by Shyi-Kuan Ou in partial fulfillment of the requirements for the $\mathrm{PhD}$ degree. Research supported in part by the Council of Agriculture, Executive Yuan, Republic of China. Research also supported by U.S. Dept. of Agriculture Hatch Act Funds and the Texas Agricultural Experiment Station. The cost of publishing this paper was defrayed in part by the payment of page charges. Under postal regulations, this paper therefore must be hereby marked advertisement solely to indicate this fact. ${ }^{1}$ Former Graduate Research Assistant. Currently, Associate Horticulturist, Taiwan Agricultural Research Institute, 189 Chung-cheng Rd., Wu-Feng 41301, Taichung, Taiwan, Republic of China. ${ }^{2}$ Professor. To whom reprint requests should be addressed.

${ }^{3}$ Geneticist.
1928, 1935; Swingle, 1928); keeping quality (Nebel, 1936); and shell splitting (Whitehouse et al., 1964)

"Northern" pecan cultivars are adapted to a shorter growing season (160 to 180 days) as compared to 190 to 220 days for "southern" cultivars (Malstrom et al., 1978). Also, Madden and Tisdale (1975) reported that chilling and stratification were needed to after-ripen seeds of some northern cultivars; although after-ripening was not necessary, it promoted the rate of germination. Conversely, most southern cultivars will easily germinate without stratification. This difference raises the possibility that northern cultivars (those with parentage from the northern portion of the natural range of pecan) are relatively resistant to viviparity. This northern-southern relationship suggests genetic control over viviparity. Such control of viviparity has been shown in Arabidopsis thaliana $\mathrm{L}$. to occur via a single gene that minimizes abscisic acid (ABA) production in the developing embryo (Karssen, et al., 1983). Endosperm (maternal) ABA was not closely related to the phenomena, whereas embryo ABA (regulated by both the female and male genome) was closely related to premature germination. Therefore, Bruce Wood (personal communication) postulated that a) similar mechanisms are likely to occur in other plant species; b) pecan pollen from northern genotypes (as compared to southern) are more likely to possess genes that act to maximize ABA in embryos because of strong selection pressure against seeds in which dormancy could be prematurely satisfied (this selection pressure would likely be much less intense in southern germplasm); and c) in general, fertilization with northern pollen would act to reduce the occurrence of viviparity via enhanced embryonic ABA levels. This study therefore presents data supporting the hypothesis that viviparity can be regulated by pollen source.
The effect of pollen parent on delayed nut germination was studied in the Royalty Pecan Orchard in Burleson County, Texas. Parental parents consisted of two "southern-adapted" viviparous-prone cultivars ['Cherokee' (protandrous Type I) and 'Wichita' (protogynous Type II)] and one "northernadapted" nonviviparous-prone cultivar ['Johnson' (Type II)]. The maternal parent for all crosses was 'Wichita'.

Four 'Wichita' trees were selected for pollination with each of the three pollen sources. Each tree served as a replication. The pistillate blossoms were covered with cellulose bags $(3.8 \times 15 \mathrm{~cm})$ as soon as the blossoms were visible and before there was any evidence of stigma receptivity. The bags were tied in place over a layer of cotton wrapped around the stem just below the inflorescence to ensure that pistillate flowers were not pollinated with an unexpected pollen source (Smith and Romberg, 1940).

Catkins were collected and placed on brown paper 2 or 3 days before natural dehiscence and dried for several days. Pollen was cleaned by passing through a $0.074-\mathrm{mm}$ sieve. A small amount of pollen of the desired male parent was injected through a needle inserted through the cotton plug described above. Flowers were pollinated twice at 3-day intervals to ensure the presence of viable pollen at stigma receptivity.

Bags were removed $\approx 30$ days after pollination. Thirty days has been used by U.S. Dept. of Agriculture pecan breeders for many years because it prevents pecan nut case bearer damage. Normal commercial pesticide sprays were used on all trees. The number of fruit was counted 30 and 60 days after pollination. 'Wichita' fruit were harvested just before perianth splitting, i.e., when the perianth had separated from the shell to the extent that markings were present on the shells. This extremely early harvest, although atypical by commercial standards, was necessary to capture all of the fruit at the critical stage when each fruit serves as its own incubation chamber. Twenty nuts were selected from each of four 'Wichita' trees that had been hand-pollinated with either 'Cherokee', 'Wichita', or 'Johnson' pollen. There was a total of 20 nuts from each cross from each of four replications, for a total of 80 nuts. The experiment was repeated a second year using the same trees in the same orchard. Harvested fruit were placed in polyethylene bags of vermiculite moistened with $0.05 \%$ a.i. cis- $N$-tricloromethylthio-4cyclohexene-1,2-dicarboximide (Captan) fungicide and then incubated at $25 \mathrm{C}$ and observed for germination characteristics. Germination data were recorded for 60 days at 5-day intervals. Germination was noted when the radicle emerged from the involucure.

\section{Results and Discussion}

Germination of nuts from the 'Wichita' $x$ 'Johnson' cross as compared to the 'Wichita' $x$ 'Cherokee' cross was much less for both 
years (Table 1). 'Johnson' pollen delayed germination of 'Wichita' nuts on all dates compared with 'Wichita' and 'Cherokee' pollen (Table 1). This delayed germination may possibly be caused by the manifestation of a dormancy-related characteristic that may be typical of northern cultivars.

These data indicate that germination of 'Wichita' nuts was influenced by some dominant genetic factor associated with the 'Johnson' pollen. If this result can be repeated with other northern- and southern-adapted cultivars, it may be taken as evidence that the viviparity problem typically exhibited by cultivars adapted for growing in mild or subtropical climates may be potentially neutralized if trees are pollinated by northern-adapted parents or those possessing such genes. While these data do not provide direct evidence that viviparity can be regulated by genes associated with northern-adapted cultivars, there is evidence that postharvest germination is influenced in such a manner. It is reasonable to expect that there is a close relationship between these two situations; thus, the idea that viviparity can be decreased by pollen of northern-adapted cultivars remains viable.

\section{Literature Cited}

Avramov, L. and G. Telenkovic. 1961. The influence of parental varieties on the germination of hybrid seeds in vine. Arhiv Poljoprivredne Nauke 14:60-73.

Brison,F.R. 1974. Pecan culture. Texas Pecan Growers' Assn., College Station.

Finch, A.H. 1933. Notes on pecan filling and maturity. J. Amer. Soc. Hort. Sci. 30:387-391.

Finch, A.H. and C.W. Van Horn. 1936. The physi-

Table 1. Effect of pollen from three different cultivars on the accumulated germination percentage of nuts using 'Wichita' as the maternal parent.

\begin{tabular}{|c|c|c|c|c|c|c|c|c|c|}
\hline \multirow{2}{*}{$\begin{array}{l}\text { Pollen } \\
\text { parent }\end{array}$} & \multicolumn{8}{|c|}{ Days incubated at $25 \mathrm{C}$} & \multirow[b]{2}{*}{$\mathrm{LSD}_{0.05}$} \\
\hline & 25 & 30 & 35 & 40 & 45 & 50 & 55 & 60 & \\
\hline \multicolumn{10}{|c|}{1987} \\
\hline Cherokee & 63.5 & 66.7 & 70.7 & 71.4 & 75.2 & 76.5 & 79.1 & 79.1 & 16.8 \\
\hline Wichita & 51.7 & 68.1 & 70.3 & 70.3 & 70.3 & 70.3 & 70.3 & 70.3 & 16.0 \\
\hline Johnson & 26.5 & 30.1 & 33.5 & 36.4 & 37.2 & 38.4 & 39.1 & 41.1 & 5.4 \\
\hline $\operatorname{LSD}_{0.05}{ }^{y}$ & 13.4 & 14.1 & 13.6 & 13.8 & 14.2 & 14.6 & 15.5 & 15.8 & \\
\hline \multicolumn{10}{|c|}{1988} \\
\hline Cherokee & 72.6 & 76.6 & 78.8 & 80.4 & 81.4 & 81.6 & 81.9 & 82.3 & 6.6 \\
\hline Wichita & 78.3 & 82.7 & 83.4 & 83.8 & 84.0 & 84.2 & 84.2 & 84.4 & 10.0 \\
\hline Johnson & 18.9 & 28.2 & 42.7 & 46.1 & 49.6 & 51.2 & 53.7 & 60.2 & 28.1 \\
\hline $\operatorname{LSD}_{0.05^{y}}$ & 13.3 & 14.0 & 22.4 & 21.9 & 23.2 & 23.2 & 21.0 & 16.7 & \\
\hline
\end{tabular}

${ }^{\mathrm{z}}$ Means separation by day intervals, using LSD, $P \leq 0.05$.

${ }^{\mathrm{y}}$ Means separation by pollen parents, using LSD, $P \leq 0.05$.

ology and control of pecan nut filling and maturity. Arizona Agr. Expt. Sta. Res. Bul. 62.

Iyer, C.P.A. and G.S. Randhawa. 1965. Hybridization studies in grapes-Investigations on the direct influence of pollen on some fruit and seed characters. Indian J. Hort. 22:107-121.

Karssen, C.M., D.L.C. Brinkhorst-van der Swan, A.E. Breekland, and M. Koornneff. 1983. Induction of dormancy during seed development by endogenous abscisic acid: Studies of abscisic acid deficient genotypes of Arabidopsis thaliana (L.) Heynh. Planta 157:158-165.

Madden, G.D. and H.W. Tisdale. 1975. The effects of chilling and stratification on nut germination of northern and southern pecan cultivars. HortScience 10:259-260.

Malstrom, H.L., G.D. Madden, and L.D. Romberg. 1978. Evaluation of pecan and origin. The Pecan Quarterly 12(4):24-28.

Nebel, B.R. 1936. Metaxenia in apples. J. Hered. 27:345-349.

Nixon, R.W. 1928. Immediate influence of pollen in determining the size and time of ripening of the fruit of the date palm. J. Hered. 19:241-255.

Nixon, R.W. 1935. Metaxenia in dates. J. Amer. Soc. Hort. Sci. 22:221-226.

Smith, C.L. and L.D. Romberg. 1940. Stigma receptivity and pollen shedding in some pecan varieties. J. Agr. Res. 60:551-564.

Stein, L.A. 1985. The influence of fertilization, phloem restriction, irrigation, microbes, and ethephon on pecan shuck disorders in Texas. $\mathrm{PhD}$ Diss., Texas A\&M Univ., College Station.

Swingle, W.T. 1928. Metaxenia in the date palm. J. Hered. 19:257-268.

Uppal, D.K. and S.K. Mukherjee. 1969. Metaxenia in grapes. Indian J. Hort. 26:5-14.

Whitehouse, W.E., E.K. Koch, J.C. Jones, and C.L. Stone. 1964. Influence of pollens from diverse pistachio nuts. J. Amer. Soc. Hort. Sci. 84:224229.

Zertuche, M.I. 1986. Effect of gibberellins, abscisic acid, various irrigation treatments, and different levels of nitrogen and potassium upon viviparity of pecans (Carya illinoensis (Wang) K. Koch). PhD Diss., Texas A\&M Univ., College Station. 